\title{
Critical Thinking Dispositions of Social Studies Teacher Candidates
}

\author{
Salih USLU \\ Niğde Ömer Halisdemir University, Turkey. \\ Email:salihush@ohu.edu.tr
}

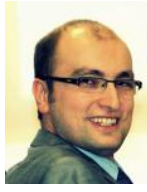

\begin{abstract}
The main aim of this study is, to analyze critical thinking disposition of social studies teacher candidates. The study group is consisting of totally 250 teacher candidates voluntarily who are students of education faculty at social studies department in a state university. This study is used with descriptive survey method. The "Personal Information Form" was developed by the researchers used as data collection tools and The California Critical Thinking Disposition Inventory (CCTDI-R) which was developed by Facione, Facione, and Giancarlo (1998) and translated into Turkish by Kökdemir (2003) was used. Research data were analyzed with IBM SPSS 21.0 program. The independent samples t-test and One Way ANOVA were used for analyzing the datum. At the end of the study, it has been determined that in generally social studies teacher candidates have low level critical thinking disposition, obtained the average score related with subscales while the highest scores at the Analyticity subscale, the lowest average scores at Systematicity subscale. It has been seen that critical thinking disposition were not differentiated in terms of gender and class variables generally while significant differences were detected in the subscale dimensions. Some suggestions have been made in the light of these findings.
\end{abstract}

Keywords: Social studies, Critical, Critical thinking, Critical thinking disposition, Teacher candidates, Thinking.

Citation | Salih USLU (2020). Critical Thinking Dispositions of Social Studies Teacher Candidates. Asian Journal of Education and Training, 7(1): 72-79.

History:

Received: 12 November 2019

Revised: 19 December 2019

Accepted: 27 January 2020

Published: 24. February 2020

Licensed: This work is licensed under a Creative Commons

Attribution 3.0 License $(\mathrm{cc})$ )

Publisher: Asian Online Journal Publishing Group
Funding: This study received no specific financial support.

Competing Interests: The author declares that there are no conflicts of interests regarding the publication of this paper.

Transparency: The author confirms that the manuscript is an honest, accurate, and transparent account of the study was reported; that no vital features of the study have been omitted; and that any discrepancies from the study as planned have been explained.

study as planned have been explained.
Ethical: This study follows all ethical practices during writing.

\section{Contents}

1. Introduction.

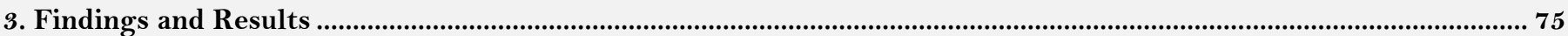

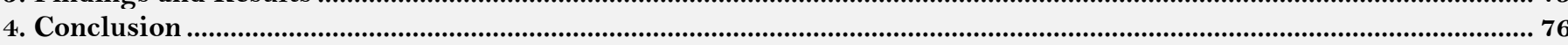

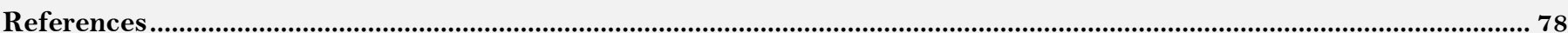




\section{Contribution of this paper to the literature}

This study contributes to the existing literature by analyzing critical thinking disposition of social studies teacher candidates. The study group is consisting of totally 250 teacher candidates voluntarily who are students of education faculty at social studies department in a state university. This study is used with descriptive survey method.

\section{Introduction}

At though information era nowadays, it is considered that the students' active participation process is more important than the teachers present in education. Also it has become important the students critical thinking skills in which case can be used effectively as the importance of the students' knowledge processing method (Oztürk \& Dilek, 2005). One of the important features that today's individuals are expected to have is the problem solving skill. As is known, human beings have confronted various problems throughout history and it is clear that these problems will continue increasingly in the future (Doğanay, 2000). Today, members of any profession should easily adapt to developments and innovations, choose knowledge wisely, produce creative ideas, behave flexibly, and improve their characteristics; shortly, achieve modern professional qualifications. The achievement of these qualifications is possible through modern education which aims to help students internalize basic concepts and analyze/solve the problems using critical thinking skills (Oztürk. \& Ulusoy, 2008). Without incorporating core competence programs into college teaching programs it is impossible for college students to form and develop their core competence, such as global vision, critical thinking, innovative ability, social and state responsibility, lifelong learning, entrepreneurship and leadership coordination (Gu \& Zhao, 2018). With modern educational processes, it is aimed to raise individuals who think sophisticatedly, produce, search, question, approach new knowledge and situations skeptically and have critical viewpoint (Tural \& Seçgin, 2012). The acquisition of critical thinking skills by students at school followed by the use of these skills throughout one's life is of great importance. By attaching such a great emphasis to critical thinking skills in school curriculum, students can be rendered more autonomous, they can make greater contributions to the social problems experienced in today's world, they can be critical observers and supporters of democratic institutions and human rights, and they can easily proceed in their careers (Cam Aktaş \& Güven, 2015).

Critical thinking is described as an important skill in general education and is referred to as a 21 st century skill (Sagun, Ateskan, \& Onur, 2016). Critical thinking which is one of the important element of the contemporary education is defined in different ways in the literature. The term critical thinking is widely used in the fields of education, psychology, and philosophy, and there have been repeated attempts to define the concept in order to increase the understanding of how this cognitive ability can be utilized (Bell \& Loon, 2015). Some of these definitions are:

\subsection{Critical Thinking}

(i) Is to invert the students' behavior by evaluating their thinking skills with applying to a topic in terms of they are all known (Norris, 1985).

(ii) Is a form of reflective thinking and acceptable that focusing on what is believed in or what is done (Norris. \& Ernis, 1989).

(iii) Is to draw a conclusion based on observation and information (Paul, 1991).

(iv) Is cognitive active and organized process that aims to be able to understand ourselves and events in near surrounding by being aware of our own thought process, keeping in mind the others' thought process, applying what we have learnt (Cüceloğlu, 1994).

(v) Is using cognitive skills or strategies which increase the likelihood of desired behavior (Halpern, 1996).

(vi) Is to think on how he is performing while thinking for improving the person's own thinking (Paul. \& Elder, 2006).

(vii) Is a reasoning process based on information. Critical thinkers consider the others thinking process as well as being aware of why and how the thinking process (Doğanay. \& Unal, 2006).

There are five basic features of critical thinking. These can be listed follows (Ozden, 2014):

(i) Critical thinking requires to be active: we use our intelligent, knowledge, memory and cognitive skills actively during critical thinking. One thinking actively cannot stay out of event that effect himself and tries to give direction them.

(ii) Critical thinking requires individuals to be independent: critical thinking does not accept any pre-judgment and is based on no authority.

(iii) Critical thinking requires to be open mind to new ideas: Critical thinkers revise their ideas with others' and enrich their thoughts by taking different ideas that must be taken.

(iv) Critical thinking requires to take into account evidence and reasons supporting with the ideas: Critical thinkers explain the reasons and evidence of the ideas put forward.

(v) Critical thinking requires organization: It provides to explain easily what reason, what result, what evidence, which ideas essential, which ideas ensure.

Critical thinking dispositions are listed by Kökdemir (2003):

(i) Truth-Seeking: In this dimension that contains assessment dispositions of options or different from each ideas, one behaves questioning for truth, tending to be objective to the ideas that are in the opposite to his own ideas.

(ii) Open Mindedness: It means that one be in tolerance to different approaches and be sensitive to his mistakes. In this dimension, one takes into account also the others opinion for any decision.

(iii) Analyticity: one behaves to be wary to situations that could cause problems and to use reasoning skills to even the difficult problems and to use objective evidence.

(iv) Systematicity: Any research tends to be organized, planned and careful research.

(v) Self-Confidence: It represents individuals' confidence in their own reasoning process. 
(vi) Inquisitiveness: it reflects that one gives into getting information and learning new things without any interest or expectation.

(vii) Maturity: It means mental maturity and cognitive development.

With the result of deep changes in the educational programs seen in Turkey since 2005, constructive educational programs have begun to be applied. Among various reforms brought by this educational program, basic skills have been given importance including critical thinking. There are various objectives and activities about critical thinking in this program. Therefore, much research has been done to gain critical thinking skills since 2005 (Polat, 2015). The research combining critical thinking with subject teaching was very common, including nursing, writing, reading, philosophy, accounting, statistics, information and mathematics, also involving art, literature, economy, environment sanitation, electronic, investigating, media and library retrieving (Zhou, Yan, Zhao, Liu, \& Xing, 2012). When the related literature was been analyzed there were a large number of samples studies about this subject performed in various areas and with teachers and teacher candidates in various events (Bostic, 1988; Dam \& Volman, 2004; Facione et al., 1998; Facione., Sanchez, Facione, \& Gainen, 1995; Gadzella \& Masten, 1998; Krank, 1994; Paul.. 1993; Zhang, 2003).

It is seen that the studies performed on critical thinking have discussed in two dimensions as they have been carried out in literature: Critical thinking skills and critical thinking disposition. Critical thinking skills is not same with critical thinking disposition. However, there is a relationship between critical thinking skills and critical thinking disposition. One who has critical thinking skills may not think critically. This is related with one's attitude and disposition about critical thinking. Therefore, critical thinking dispositions are also investigated as much as critical thinking skills studies in literature (Tortop \& Eker, 2013).

It is necessary that teachers should think critically as a part of being good at their professions, have deep learning approach and be aware of the importance of learning styles which affect their students learning level whose raised up (Beşoluk \& Onder, 2010). Considering that one can not teach anything that they do not know to anyone, it is clear that the teachers who do not have critical thinking skills and critical thinking disposition cannot help their students with with these issues. The situation for developing thinking dispositions must be providing to the teacher candidates who raise up people in pre-service training to teachers educate for raising up person has critical thinking disposition. Hence, it may be stated that, in order to train teachers who will provide their students with critical thinking skills, it is necessary to investrigate teacher candidates' critical thinking dispositions and to perform activities that will improve their critical thinking dispositions In this regard, the purpose of this study is to investigate the critical thinking dispositions of social studies teacher candidates. No study that aims to analyze critical thinking dispositions of social studies teacher candidates has been found in literature. Therefore, this study is expected to contribute to literature.

Education, age, academic success, socio-economic status, participation in scientific and social activities, patents' education status, parents' profession can be listed among the factors of affecting critical thinking (Oztürk. \& Ulusoy, 2008). In way to the study purpose gender and class variables have been put the work for analyzing critical thinking dispositions of the social studies teacher candidates. For the study these independent variables were chosen by the reason of the most commonly used variables in the literature. In addition, they were thought that affecting critical thinking dispositions of social studies teacher candidates.

In summary, the study's main aim is to analyze critical thinking dispositions of social studies teacher candidates (SSTC). For this purpose, these are questioned:

1. How is SSTC' critical thinking dispositions?

2. Do SSTC' critical thinking dispositions differentiate in terms of gender?

3. Do SSTC' critical thinking dispositions differentiate in terms of class levels?

\section{Method}

\subsection{Research Design}

This research was carried out in the descriptive scanning model. Descriptive scanning is used in a highly widespread manner in the field of education; because it helps researchers summarize the characteristics (skills, preferences, behaviors, attitudes etc.) of individuals, groups or physical settings (e.g. schools) (Büyüköztürk, Cakmak, Akgün, Karadeniz, \& Demirel, 2010).

\subsection{Data Collection and Data Processing}

The study group is consist of totally 250 teacher candidates voluntarily who are students of education faculty at social studies department in a state university.

The data have been obtained by using "Personal Information Form" and "California Critical Thinking Disposition Inventory”. The 'Personal Information Form' prepared by the researcher contains information about gender and class variables of social studies teacher candidates who participated in the study.

As a data collection tool, The California Critical Thinking Disposition Inventory (CCTDI-R) which was developed by Facione et al. (1998) and translated into Turkish by Kökdemir (2003) was used.

California Critical Thinking Disposition Inventory was translated into Turkish by Kökdemir (2003) and factor, reliability and validity analyzes were performed. New scale, which consists totally 6 subscales and 51 items, internal consistency coefficient (Cronbach Alpha) was found 0.88. Also the internal consistency of each dimension (Cronbach Alpha); 0.75 is for Analitcity Subscale and Open-Mindedness Subscale; 0.78 is for Inquisitiveness Subscale; 0.77 is for Self-confidence Subscale; 0.62 is for the Truth-Seeking Subscale; 0.63 is for Systematicity Subscale. In scale, six rating was used as the highest option "completely agree" (6) and the lowest option "disagree" (1). Raw scores were computed for each subscale by answers responded to 6-point Likert type scale were collected, negative items were collected by giving points in the opposite direction and these raw scores were converted to a standard score in the lowest value 6 to the highest value 60 after they were multiplied 10 and divided by the number of questions. The presumptive lowest and highest values are substantive for all subscales. Considered CCTDI scale in terms of sub dimensions, it refers to have score less than 40 low, 40-50 positive, more than 50 high 
critical thinking. When CCTDI is taken as a whole, the general critical thinking dispositions levels of individuals whose scores are lower than $240(40 \times 6)$ are low while the general critical thinking dispositions levels of individuals whose scores are over 300 (50X6) are high (Kökdemir, 2003).

While Original California Critical Thinking Disposition Inventory's sub inventories Cronbach Alpha reliable coefficients change between .60 and .78, the inventory's Cronbach Alpha reliable coefficient .90 has been found for total grade. While in Kökdemir's research the sub dimensions of the inventory of Cronbach Alfa reliable coefficients change between .61 and .78, the total of the inventory's Cronbach Alpha reliable coefficient has been found .88 (Kökdemir, 2003). In this research the inventory's total Cronbach Alpha reliable coefficient has been found .82 .

At the study, IBM SPSS 21.0 "Statistical Package for the Social Sciences" packed program was used for analyzing data obtained from performed scale and significance level was taken as $\mathrm{p} \leq .05$ in all analyze performed. The data were tested with the appropriate analysis techniques on the variables. Mean $(\overline{\mathrm{X}})$ and Standard Deviation (S) were used at evaluating SSTC' thinking dispositions in terms of factors while analyzing the datum. Independent samples t-test and one-way ANOVA, which are among parametric analysis techniques, were used in order to determine the total score that obtained from the scale, whether they differ from in terms of the independent variables. Homogeneity of variance was checked for determining the differences between the groups in which situations whether significant differences arises at analysis result. Bonferroni test from multiple comparison was used if there is variance in the homogeneous.

\section{Findings and Results}

3.1. Findings Regarding to the California Critical Thinking Disposition Inventory and Its' Subscales

The scores of SSTC obtained from the California Critical Thinking Disposition Inventory and its' subscales see Table 1.

Table-1. The descriptive data related the scores of SSTC obtained from the California critical

\begin{tabular}{l|c|c} 
thinking disposition inventory and its' subscale. \\
\hline Sub Scales & $\overline{\mathrm{X}}$ & $\mathbf{S}$ \\
\hline Truth-Seeking & 24.22 & 5.50 \\
\hline Open Mindedness & 39.33 & 9.22 \\
\hline Analyticity & 47.52 & 7.32 \\
\hline Systematicity & 20.77 & 4.18 \\
\hline Self-Confidence & 28.30 & 6.29 \\
\hline Inquisitiveness & 37.38 & 6.87 \\
\hline Total & 197.52 & 27.34 \\
\hline
\end{tabular}

It is seen that the average scores of SSTC' California Critical Thinking Disposition Inventory is 197.52 at Table 1. This value shows in terms of total scores the level of SSTC' critical thinking dispositions are low. It is seen that SSTC' highest average score $(\overline{\mathrm{X}}=47.52)$ is taken from Analyticity subscale and the lowest average score ( $\overline{\mathrm{X}}=20.77)$ is taken from Systematicity subscale. It is found that SSTC' critical thinking dispositions are positive at only Analyticity subscale and they are lower at the other subscales.

\subsection{Finding Regarding to Gender Variable}

Whether there is a significant difference between SSTC' gender and SSTC' critical thinking dispositions for independent samples analyzed by t-test and results Table 2

Table-2. T-test results regarding to gender of SSTC' scores obtained from the California critical thinking disposition inventory

\begin{tabular}{|c|c|c|c|c|c|c|}
\hline Sub inventories & Gender & $\bar{n}$ & $\overline{\bar{X}}$ & $\bar{S}$ & $\mathrm{t}$ & $\bar{p}$ \\
\hline \multirow{2}{*}{ Truth-Seeking } & Female & 119 & 23.59 & 5.03 & \multirow{2}{*}{1.736} & \multirow{2}{*}{.084} \\
\hline & Male & 131 & 24.80 & 5.85 & & \\
\hline \multirow{2}{*}{ Open Mindedness } & Female & 119 & 38.27 & 8.96 & \multirow{2}{*}{1.730} & \multirow{2}{*}{.085} \\
\hline & Male & 131 & 40.29 & 9.38 & & \\
\hline \multirow{2}{*}{ Analyticity } & Female & 119 & 47.74 & 6.65 & \multirow{2}{*}{.468} & \multirow{2}{*}{.640} \\
\hline & Male & 131 & 47.31 & 7.90 & & \\
\hline \multirow{2}{*}{ Systematicity } & Female & 119 & 20.55 & 3.86 & \multirow{2}{*}{.768} & \multirow{2}{*}{.443} \\
\hline & Male & 131 & 20.96 & 4.46 & & \\
\hline \multirow{2}{*}{ Self-Confidence } & Female & 119 & 27.42 & 6.33 & \multirow{2}{*}{2.097} & \multirow{2}{*}{$.037^{*}$} \\
\hline & Male & 131 & 29.09 & 6.18 & & \\
\hline \multirow{2}{*}{ Inquisitiveness } & Female & 119 & 36.43 & 6.68 & \multirow{2}{*}{2.086} & \multirow{2}{*}{$.038^{*}$} \\
\hline & Male & 131 & 38.23 & 6.95 & & \\
\hline \multirow{2}{*}{ Total } & Female & 119 & 194.04 & 24.77 & \multirow{2}{*}{1.947} & \multirow{2}{*}{.053} \\
\hline & Male & 131 & 200.69 & 29.21 & & \\
\hline
\end{tabular}

Note: ${ }^{*} \mathrm{p}<.05$

When Table 2 is examined, there was not a significant difference at Truth-Seeking $\left(\mathrm{t}_{(248)}=1.736 ; \mathrm{p}>\right.$.05), Open Mindedness $\left(\mathrm{t}_{(248)}=1.730 ; \mathrm{p}>.05\right)$, Analyticity $\left(\mathrm{t}_{(248)}=.468 ; \mathrm{p}>.05\right)$, Systematicity $\left(\mathrm{t}_{(248)}=.768 ; \mathrm{p}>.05\right)$ subscales and at the California Critical Thinking Disposition Inventory scale $\left(\mathrm{t}_{(248)}=1.947 ; \mathrm{p}>.05\right)$ generally between SSTC' gender and critical thinking dispositions. However, there was a significant difference at Self-Confidence $\left(\mathrm{t}_{(248)}=2.097\right.$; $\mathrm{p}<.05)$ and Inquisitiveness $\left(\mathrm{t}_{(248)}=2.086 ; \mathrm{p}<.05\right)$ subscales in terms of SSTC' gender and critical thinking dispositions. When the arithmetic average scores are observed, the difference is in favor of SSTC' male. This finding can be interpreted that, critical thinking dispositions are positive for SSTC' male at Self-Confidence and Inquisitiveness subscales to SSTC' female. 


\subsection{Findings Regarding to Class Variable}

Whether there is a significant difference between SSTC' class levels and SSTC' critical thinking dispositions analyzed by One-Way ANOVA and results Table 3

Table-3. The one-way ANOVA results in terms of class level of SSTC' scores obtained from the California critical thinking disposition inventory and its' subscale.

\begin{tabular}{|c|c|c|c|c|c|c|c|c|c|c|}
\hline \multirow[b]{2}{*}{ 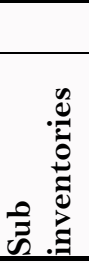 } & \multicolumn{4}{|c|}{ Descriptive data } & \multicolumn{6}{|l|}{ ANOVA results } \\
\hline & Class & $\mathbf{n}$ & $\overline{\mathrm{X}}$ & $\mathbf{S}$ & Variance source & Sum of squares & DF & $\begin{array}{l}\text { Mean } \\
\text { square }\end{array}$ & $\mathbf{F}$ & $\mathbf{p}$ \\
\hline \multirow{5}{*}{ 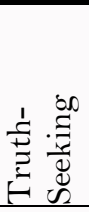 } & 1 & 69 & 23.63 & 5.30 & Between Groups & 57.77 & 3 & 19.257 & \multirow{3}{*}{.633} & \multirow{3}{*}{.594} \\
\hline & 2 & 48 & 24.00 & 5.32 & Within Groups & 7478.23 & 246 & 30.399 & & \\
\hline & 3 & 93 & 24.80 & 5.92 & Total & 7536.00 & 249 & & & \\
\hline & 4 & 40 & 24.17 & 5.06 & & & & & & \\
\hline & Total & 250 & 24.22 & 5.50 & & & & & & \\
\hline \multirow{5}{*}{$\frac{\stackrel{\infty}{0}}{\stackrel{D}{0}}$} & 1 & 69 & 36.43 & 8.09 & Between Groups & 1352.72 & 3 & 450.909 & \multirow{3}{*}{5.594} & \multirow{3}{*}{$.001 *$} \\
\hline & 2 & 48 & 39.31 & 7.97 & Within Groups & 19828.71 & 246 & 80.605 & & \\
\hline & 3 & 93 & 42.07 & 10.40 & Total & 21181.44 & 249 & & & \\
\hline & 4 & 40 & 37.97 & 7.88 & \multirow{2}{*}{\multicolumn{4}{|c|}{$\begin{array}{l}\text { Difference (Bonferroni) } \\
1-3\end{array}$}} & & \\
\hline & Total & 250 & 39.33 & 9.22 & & & & & & \\
\hline \multirow{5}{*}{ 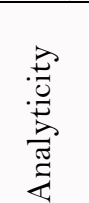 } & 1 & 69 & 49.92 & 6.25 & Between Groups & 1274.19 & 3 & 424.733 & \multirow{3}{*}{8.642} & \multirow{3}{*}{$.000 *$} \\
\hline & 2 & 48 & 49.54 & 5.10 & Within Groups & 12090.20 & 246 & 49.147 & & \\
\hline & 3 & 93 & 44.82 & 8.84 & Total & 13364.40 & 249 & & & \\
\hline & 4 & 40 & 47.20 & 5.08 & \multirow{2}{*}{\multicolumn{4}{|c|}{$\begin{array}{l}\text { Difference (Bonferroni) } \\
1-3,2-3\end{array}$}} & & \\
\hline & Total & 250 & 47.52 & 7.32 & & & & & & \\
\hline \multirow{5}{*}{ 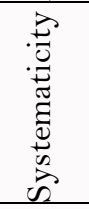 } & 1 & 69 & 20.05 & 3.23 & Between Groups & 185.56 & 3 & 61.853 & \multirow{3}{*}{3.643} & \multirow{3}{*}{$.013 *$} \\
\hline & 2 & 48 & 20.79 & 3.80 & Within Groups & 4176.98 & 246 & 16.980 & & \\
\hline & 3 & 93 & 21.78 & 4.92 & Total & 4362.54 & 249 & & & \\
\hline & 4 & 40 & 19.60 & 3.76 & \multirow{2}{*}{\multicolumn{4}{|c|}{$\begin{array}{l}\text { Difference (Bonferroni) } \\
3-4\end{array}$}} & & \\
\hline & Total & 250 & 20.76 & 4.18 & & & & & & \\
\hline \multirow{5}{*}{ 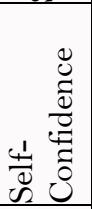 } & 1 & 69 & 28.31 & 6.16 & Between Groups & 1.16 & 3 & .390 & \multirow{3}{*}{.010} & \multirow{3}{*}{.999} \\
\hline & 2 & 48 & 28.31 & 5.86 & Within Groups & 9877.33 & 246 & 40.152 & & \\
\hline & 3 & 93 & 28.22 & 6.70 & Total & 9878.50 & 249 & & & \\
\hline & 4 & 40 & 28.42 & 6.27 & & & & & & \\
\hline & Total & 250 & 28.30 & 6.29 & & & & & & \\
\hline \multirow{5}{*}{ 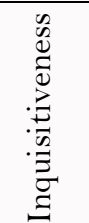 } & 1 & 69 & 36.75 & 6.23 & Between Groups & 106.02 & 3 & 35.342 & \multirow{3}{*}{.746} & \multirow{3}{*}{.525} \\
\hline & 2 & 48 & 38.58 & 5.79 & Within Groups & 11648.87 & 246 & 47.353 & & \\
\hline & 3 & 93 & 37.43 & 7.74 & Total & 11754.90 & 249 & & & \\
\hline & 4 & 40 & 36.90 & 6.99 & & & & & & \\
\hline & Total & 250 & 37.38 & 6.87 & & & & & & \\
\hline \multirow{5}{*}{$\stackrel{\pi}{0}$} & 1 & 69 & 195.13 & 20.81 & Between Groups & 1500.69 & 3 & 500.231 & & \\
\hline & 2 & 48 & 200.54 & 21.12 & Within Groups & 184627.61 & 246 & 750.519 & .667 & .573 \\
\hline & 3 & 93 & 199.15 & 35.41 & Total & 186128.30 & 249 & & & \\
\hline & 4 & 40 & 194.27 & 21.97 & & & & & & \\
\hline & Total & 250 & 197.52 & 27.34 & & & & & & \\
\hline
\end{tabular}

When the Table 3 is examined, there was not a significant difference at Truth-Seeking $\left(\mathrm{F}_{(3-246)}=.633, \mathrm{p}>.05\right)$, Self-Confidence $\left(\mathrm{F}_{(3-246)}=.010, \mathrm{p}>.05\right)$, Inquisitiveness $\left(\mathrm{F}_{(3-246)}=.746, \mathrm{p}>.05\right)$ subscales and the California Critical Thinking Disposition Inventory scale generally between SSTC' class levels and critical thinking dispositions. However there is a significant difference at Open Mindedness $(\mathrm{F}(3-246)=5.594, \mathrm{p}<.05)$, Analyticity $\left(\mathrm{F}_{(3-246)}=8.642\right.$, $\mathrm{p}<.05)$ and Systematicity $\left(\mathrm{F}_{(3-246)}=3.643, \mathrm{p}<.05\right)$ subscales in terms of SSTC' class variable.

One Way ANOVA analysis of variance resultsshowed that thare was a significant difference. Therefore, homogeneity of variance was controlled for determining differences in which groups. Bonferroni test in multiple comparison tests used because of the homogeneity of variances. According to Bonferroni multiple comparison test results: It is seen that the critical thinking dispositions of SSTC' g $^{\text {rd }}$ grade $(\overline{\mathrm{X}}=42.07)$ is more positive than SSTC' $1^{\text {st }}$ grade $(\overline{\mathrm{X}}=36.43)$ at Open Mindedness sub dimension. Also the critical thinking dispositions of SSTC' $1^{\text {st }}$ grade $(\overline{\mathrm{X}}=49.92)$ and $2^{\text {nd }}$ grade $(\overline{\mathrm{X}}=49.54)$ are more positive than $3^{\text {rd }}$ grade $(\overline{\mathrm{X}}=44.82)$ at Analyticity sub dimension. In addition the critical thinking dispositions of SSTC' $3^{\text {rd }}$ grade $(\bar{X}=21.78)$ is more positive than $4^{\text {th }}$ grade $(\bar{X}=19.60)$ at Systematicity sub dimension.

\section{Conclusion}

Through analysis of the critical thinking dispositions of Social Studies teacher candidates in this study, it was found that the critical thinking dispositions of SSTC' are generally low. This finding parallels with Cetinkaya (2011); Tural and Seçgin (2012). In these studies, it was found that critical thinking dispositions of participations were low. The result of critical thinking dispositions of Social Studies Teacher Candidates low in general meshes with Türnüklü and Yeşildere (2005); Dutoğlu and Tuncel (2008); Saçlı and Demirhan (2008); Sen (2009); Semerci (2010); Piji and Uzun (2013); Kuvaç and Koc (2014) findigs of studies. In these studies, it is determined that the critical thinking dispositions of participants are medium/positive. 
SSTC' scores related to subscales are obtained the highest average score from the Analyticity subscale and the lowest average score form Systematicity subscale. It is seen that SSTC' critical thinking dispositions is positive only in Analyticity subscales, the others are lower. Analyzing the related literature, it is seen that critical thinking dispositions only found lower at Türnüklü and Yeşildere (2005) study performed with math teacher candidates at Self-Confidence and Truth-Seeking subscales, the other subscales were positive. Teacher candidates critical disposition's scores found the highest at Analycity subscale and the lowest at Truth-Seeking subscale in Kuvaç and Koc (2014) study. Moreover, it is found the highest score at Analyticity and Inquisitiveness subscales and the lowest score Open Mindedness subscale in Ozsoy-Güneş, Crazy \& Peace, and Kırbaşlar (2013) study. Furthermore, it is seen that the critical thinking dispositions of participants found lower at Systematicity, Truth-Seeking and Self-Confidence subscales, positive at Inquisitiveness subscale and higher at Analyticity and Open Mindedness subscales at Cetinkaya (2011). Also, it is found that the critical thinking dispositions of participants score medium at all subscale at Piji and Uzun (2013).

According to gender there were not significant differences among Truth-Seeking, Open Mindedness, Analyticity and Systematicity subscales and in generally the California Critical Thinking Disposition Inventory scale. However, significant differences obtained at Self-Confidence and Inquisitiveness subscales. Looking at average score, the difference is in favor of SSTC' male. This finding can be said the critical thinking dispositions is more positive for SSTC' male than SSTC's female at Self-Confidence and Inquisitiveness subscales. Analyzing critical thinking disposition totally, that is determined that there is not a significant difference in terms of gender at Ozdemir (2005); Saçlı and Demirhan (2008); Ay and Akgöl (2008); Genç (2008); Korkmaz. (2009a); Ekinci and Aybek (2010) studies too. This finding is same with Rudd, Baker, and Hoover (2000); Beşoluk and Onder (2010) findings in terms of gender. In addition, this is same at Tural and Seçgin (2012) study's result according to gender. Also, at Kuvaç and Koc (2014) study, it was not obtained significant difference at the critical thinking dispositions of teacher candidates in terms of gender in total scores. At that study there is not a significant difference all subscales except Open Mindedness and Truth-Seeking subscales. At Ozsoy-Güneş et al. (2013) study, it is found that there is a significant difference in favor of females statistically when total scores and the average score of Truth-Seeking and Systematicity subscales were evaluated. However, at Emir (2012) study the critical thinking disposition of students according to gender, it is in favor of male all dimensions except Truth-Seeking sub dimension. At Cetinkaya (2011) study, total score of critical thinking according to gender seemed significant difference at Analyticity, Open Mindedness and Truth-Seeking subscales and it is determined that the female students' critical thinking dispositions is more positive than male's. At that study any significant differences are not obtained within the other sub dimensions. While it was not found that any differences related music teacher candidates according to gender variable at Piji and Uzun (2013) at Semerci (2010) study it analyzing statistically in terms of gender in generally it was not seen any significant differences. At that study Semerci (2010) according to gender it was seen significant difference at Analyticity, Open Mindedness, Inquisitiveness and Systematicity sub dimensions statistically, that differences are in favor of female except at Systematicity sub dimension.

According to class levels variable, it is obtained that there is not any significant difference at the critical thinking dispositions of SSTC' at Truth-Seeking, Self-Confidence, Inquisitiveness subscales and in generally the California Critical Thinking Disposition Inventory scale. However, there is a significant difference at the critical thinking dispositions of SSTC' in terms of class at Open Mindedness, Analyticity and Systematicity subscales. According to Bonferroni test in multiple comparison tests: The critical thinking disposition SSTC' at $3^{\text {rd }}$ grade is more positive than $1^{\text {st }}$ grade at Open Mindedness sub dimension. The critical thinking disposition SSTC' at $1^{\text {st }}$ and $2^{\text {nd }}$ grades are more positive than $3^{\text {rd }}$ grade at Analyticity sub dimension. The critical thinking disposition SSTC' at $3^{\text {rd }}$ grade is more positive than $4^{\text {th }}$ grade at Systematicity sub dimension. At Kuvaç and Koc (2014) study which analyzed related literature it is on one hand the total scores at critical thinking dispositions of teacher candidates difference in terms of class levels on the other hand at cub dimensions it has a significant difference except at SelfConfidence and Inquisitiveness sub dimensions. It is found significant statistically the groups' average scores divergence for Analyticity sub scale scores in terms of class variable at (Ozsoy-Güneş et al., 2013). In Cetinkaya (2011) study it was determined that a significant difference for the ideas of participants about critical thinking in generally at scale and Analyticity, Open Mindedness and Truth-Seeking subscales. Also in that study, the critical thinking dispositions of students' at $1^{\text {st }}$ grade is more positive than $4^{\text {th }}$ grade and the other dimensions it has not any difference in terms of class levels.

Analyzing results of studies related with critical thinking at literature, it is seen that there are wide variety of results. This situation may be result from these studies made at the different branches and different samples. Because of this it cannot possible to generalize for critical thinking dispositions and critical thinking sub dimensions in terms of average score and gender and class variables.

The basic recommendation that can be made in the light of the results of this study is that an educational environment which will encourage students to think critically should be provided at the faculties of education. Indeed, considering the results of the study by Korkmaz (2009b) which show that the education received by students at the faculties of education do not contribute to their critical thinking dispositions sufficiently, the necessity of this recommendation will be better understood. In this context, teaching-learning environment in, which encourage activities to students' critical thinking should be created rather than theoretical. The content, process and time of the course must be organized to critical thinking appropriately. At evaluation phase of the course to ask to student open-ended questions for encouraging them instead of multiple-choice questions at faculties of education. The strategies, methods and techniques which encourage critical thinking should be taught to Social Studies teacher as applied. For developing critical thinking dispositions of SSTC' a variety of elective courses and train in activities (symposia, panel, seminar, conferences, workshops, etc.) must be added to curriculum. In addition, it should be provided to schools and families so that they can collaborate on activities that could lead to critical thinking.

This study's results are limited by the study group. Therefore, the similar study aims to SSTC critical thinking dispositions not be at that time at literature while this study being examined, it is though that the similar studies with different methods and samples will contribute to literature. Plus, same study can be made with Social Studies 
teachers and it can be compared with Social Studies teacher candidates. In this way more detailed information about critical thinking disposition can be obtained.

\section{References}

Ay, S., \& Akgöl, H. (2008). Critical thinking power and gender, age and grade level. Journal of Theoretical Educational Science, 1(2), 65-75.

Bell, R., \& Loon, M. (2015). The impact of critical thinking disposition on learning using business simulations. The International Journal of Management Education, 13(2), 119-127. Available at: https://doi.org/10.1016/j.ijme.2015.01.002.

Beşoluk, S., \& Onder, I. (2010). Examination of pre-service teachers' learning approaches, learning styles and critical thinking tendencies. Elementary Education Online, 9(2), 679-693.

Bostic, J. Q. (1988). Cognitive styles: Their consolidation and relationship, beyond cognitive developmental level and critical thinking ability, to understanding science. . (Doctoral Dissertation). Texas Tech University.

Büyüköztürk, Ş., Cakmak, E. K., Akgün, Ö. E., Karadeniz, Ş., \& Demirel, F. (2010). Scientific research methods [Scientific research methods]. Ankara, Turkey: Pegem Academy.

Cam Aktaş, B., \& Güven, M. (2015). Comparison of secondary education mother tongue teaching courses in the international baccalaureate program with the national program in terms of critical thinking. Educational Sciences: Theory and Practice, 15(1), 99-123.

Cetinkaya, Z. (2011). Determining the opinions of Turkish teacher candidates on critical thinking [Determination of Turkish education teacher candidates 'views related to critical thinking]. Ahi Evran University Faculty of Education Journal, 12(3), 93-108.

Cüceloğlu, D. (1994). Think well, make the right decision [Think well, make the right decision]. Istanbul, Turkey: Sistem Publishing.

Dam, T. G., \& Volman, M. (2004). Critical thinking as a citizenship competence: Teaching strategies. Learning and Instruction, 14(4), 359-379. Available at: https://doi.org/10.1016/j.learninstruc.2004.01.005.

Doğanay, A. (2000). Creative learning [Creative thinking]. In A. Şimşek (Ed.), Democracy in class] (pp. 26-52). Ankara, Turkey: Eğitimsen Publishing.

Doğanay., A., \& Unal, F. (2006). Teaching based on content types [Teaching based on content types]. In A. Simşek (Ed.), Teaching critical thinking (Teaching of critical thinking) (209-264 ed.). Ankara, Turkey: Nobel Publishing.

Dutoğlu, G., \& Tuncel, M. (2008). The relationship between prospective teachers' critical thinking tendencies and emotional intelligence levels. Abant Izzet Baysal University Faculty of Education Journal, 5(1), 11-32.

Ekinci, Ö., \& Aybek, B. (2010). Investigation of pre-service teachers' empathic and critical thinking disposition [Analysis of the empathy and the critical thinking disposition of the teacher candidates]. Elementary Education Online [Elementary Education Online], 9(2), 816827.

Emir, S. (2012). Critical thinking disposition of education faculty students. HAYEF Journal of Education, 9(1), 34-57.

Facione, P. A., Facione, N. C., \& Giancarlo, C. A. (1998). The California critical thinking, disposition inventory test manual (revised). Millbrac. CA: California Academic Press.

Facione., P. A., Sanchez, C. A., Facione, N. C., \& Gainen, J. (1995). The disposition toward critical thinking. The Journal of General Education, 44(1), 1-25.

Gadzella, B. M., \& Masten, W. G. (1998). Relation between measures of critical thinking and learning styles. Psychological Reports, 83(3_suppl), 1248-1250. Available at: https://doi.org/10.2466/pro.83.7.1248-1250.

Genç, S. Z. (2008). Critical thinking tendencies of teacher candidates. Journal of Educational Sciences in Theory Practice [Educational Sciences: Theory and Practice], 8(1), 89-116.

Gu, Y. C., \& Zhao, C. S. (2018). Innovative research on the cultivation system of the core competence of college students. Educational Sciences: Theory and Practice, $18(6), 3844-3851$.

Halpern, D. F. (1996). Thoughts and knowledge: An introduction to critical thinking. New Jersey, London: Lawrence Erlbaum Associates.

Kökdemir, D. (2003). Decision making and problem solving under uncertainty. Doctoral Dissertation, Ankara University, Ankara, Turkey.

Korkmaz, O. (2009b). The effect of education faculties on students' critical thinking tendencies and levels. Turkish Journal of Educational Sciences, 7(4), 879-902.

Korkmaz., O. (2009a). Teachers' critical thinking level and dispositions. Ahi Evran University Kırșehir Journal of Education Faculty, 10 (1), 1-13.

Krank, H. M. (1994). Do cognitive styles and learning environment predict critical thinking performance for pre-service teachers? Dissertation Abstracts International: Humanities and Social Sciences, 54(9A), 3379.

Kuvaç, M., \& Koc, I. (2014). Critical thinking tendencies of science teacher candidates: Istanbul University example. Turkish Journal of Education, 3(2), 46-59.

Norris, S. P. (1985). Synthesis of research on critical thinking. Educational Leadership, 42(8), 40-45.

Norris., S., \& Ernis, R. (1989). Evaluating critical thinking. USA: Thinking Press and Software.

Ozdemir, S. M. (2005). Assessing university students 'critical thinking skills for some variables]. Gazi University Journal of Turkish Educational Sciences [The Journal of Turkish Educational Sciences], 3(3), 1-17.

Ozden, Y. (2014). Learning and teaching [Learning and teaching]. Ankara, Turkey: Pegema Publishing.

Ozsoy-Günes, Z., Crazy \& Peace, C., \& Kırbaşlar, F. (2013). Examining the relationship between science literacy teachers' self-efficacy levels and critical thinking disposition ¿Examine of the relationship between primary pre-service science teachers 'math literacy selfefficacies and critical thinking]. Hasan Ali Yücel Faculty of Education Journal, 19(19), 47-64.

Oztürk, C., \& Dilek, D. (2005). Life science and social studies teaching [Life science and social studies teaching]. Ankara, Turkey: PegemA Yayıncilık.

Oztürk., N., \& Ulusoy, H. (2008). Critical thinking levels of undergraduate and graduate nursing students and factors affecting critical thinking. Journal of Nursing Science and Art of Maltepe University, 1(1), 15-25.

Paul, R. W. (1991). Staff development for critical thinking: Lesson plan remodelling as the strategy. A.L. Costa (Ed.). Developing minds (A resource book for teaching thinking) (Revised Education ed.). Alexandria, Virginia: ASCD.

Paul., R., \& Elder, L. (2006). For conscientious citizens on how to detect media bias and propaganda in national and world news. The foundation for critical thinking.

Paul.., W. R. (1993). Critical thinking: How to prepare students for a rapidly changing world. Santa Rosa, CA: Foundation for Critical Thinking.

Piji, K. D., \& Uzun, Y. B. (2013). Critical thinking tendencies of music teacher candidates. Journal of Ahi Evran University Kirşehir Faculty of Education (KEFAD), $14(1), 327-345$.

Polat, S. (2015). Content analysis of the studies in Turkey on the ability of critical thinking. Educational Sciences: Theory and Practice, 15(3), 659-670.

Rudd, R., Baker, M., \& Hoover, T. (2000). Undergraduate agriculture student learning styles and critical thinking abilities: Is there a relationship? Journal of Agricultural Education, 41(3), 2-12.

Saçl, F., \& Demirhan, G. (2008). Determining and comparing critical thinking levels of students studying in physical education and sports teaching program [A Determination and comparison of critical thinking levels of students in physical education teacher training program]. Journal of Sport Sciences [Hacettepe Journal of Sport Sciences], 19(2), 92-110.

Sagun, S., Ateskan, A., \& Onur, J. (2016). Developing students for university through an international high school program in Turkey. Educational Sciences in Theory and Practice, 16(2), 439-457.

Semerci, N. (2010). Read Turkey's eastern Anatolia teacher of critical thinking disposition of the candidates in the university [Critical thinking tendencies of the student-teachers who attend to the Universities of the eastern anatolia region in Turkey]. e-Journal of New World Sciences Academy, 5(3), 858-867.

Sen, U. (2009). Evaluation of critical thinking attitudes of prospective Turkish teachers in terms of various variables. Journal of the World of Turks / Journal of World of Turks, 1(2), 69-89.

Tortop, H. S., \& Eker, C. (2013). Examining the relation between perfectionism and critical thinking tendencies of teacher candidates]. Journal of Muğla Sıtkı Koçman University Institute of Social Sciences, 31(31), 144-157. 
Tural, A., \& Seçgin, F. (2012). A research about the disposition of critical thinking of the social studies and science and technology teacher candidates. Journal of e-International Educational Research, 3(1), 63-77.

Türnüklü, E. B., \& Yeşildere, S. (2005). A view from Turkey: 11-13 age group critical thinking skills and dispositions of Mathematics teachers. Journal of Ankara University Faculty of Educational Sciences, 38(2), 167-185.

Zhang, L. F. (2003). Contributions of thinking styles to critical thinking dispositions. Journal of Psychology, 137(6), 517-544. Available at: https://doi.org/10.1080/00223980309600633.

Zhou, Q., Yan, C., Zhao, S., Liu, L., \& Xing, L. (2012). A preliminary investigation into critical thinking of in-service and pre-service middle school Chemistry teachers in Shaanxi province of China. Asia-Pacific Forum on Science Learning and Teaching, 13(2), 1-13. 